\title{
Investment appraisal and risk assessment of protected vegetable cultivation under Leyte conditions
}

\author{
Therese C. Ratilla and Moises Neil V. Seriño ${ }^{1 *}$
}

\begin{abstract}
Protected cropping technology has been introduced to address the inability of farmers to achieve a successful year-round vegetable production. However, small scale farmers are reluctant to adopt this technology due to huge investment costs and the risk associated with extreme weather conditions. Hence, this study was conducted in some parts of Leyte, to evaluate the profitability and assess the risk of protected and open-field cultivation during the occurrence of extreme weather conditions such as tropical cyclones and strong wind phenomena. Results show that protected cultivation generates higher yields compared to open field cultivation. In Baybay site, investment on steel-type high-strength-tunnel covered with polyethylene plastic is the most viable option as it attained the highest net present values (NPVs), benefit-cost ratios (BCRs) and internal rate of return (IRRs). It also has the earliest payback period across different climatic scenarios. At the Cabintan site, the low-tunnel-structure is the most viable when a high-end market is established. This implies that market outlet is one of the critical factors affecting profitability and pricing. Given the potential of protected cultivation in minimizing crop failures, it is recommended that the government and private sector shall extend financial and technical assistance to farmers. Investors shall be covered with crop and structure insurances as risk of crop failures and loss of capital is high during inclement weather conditions.
\end{abstract}

Keywords: vegetable production, profitability, risk analysis, extreme weather condition

\section{INTRODUCTION}

The vegetable industry in the Philippines is characterized by high seasonality of production due to its location and tropical climate. Its production is greatly affected by the occurence of El Niño, La Niña, northeast and southwest monsoons, since the

'Department of Economics, Visayas State University

\footnotetext{
* Corresponding Author. Address: Department of Economics, Visayas State University, Visca, Baybay City, Leyte,Philippines; Email:moisesneil.serino@vsu.edu.ph DOI: $10.32945 /$ atr39sb15.2017
} 
country is located near the Pacific Ocean and along the typhoon belt. An average 20 typhoons occur a year, five of which are destructive (Asian Disaster Reduction Center 2008). With this, farmers cannot adequately achieve a successful yearround production system. Vegetable farmers are also often faced with difficulties in producing quality products and in increasing their profit. That is why vegetable farmers tend to continue planting even during risky weather conditions just to capture a higher selling price when the supply is low. In effect, they are faced with the risk of high probability of crop damage and loss of capital. The vegetable production in Region VIII or Eastern Visayas, particularly in Leyte, is quite problematic especially during wet seasons because of its type IV rainfall. This rainfall pattern is associated with strong winds and heavy rain that usually damaged vegetable crops. Moreover, the region is also frequented by typhoons because of its proximity to the Pacific Ocean.

Protected cultivation, which can be in the form of greenhouses, direct covers, low or high tunnels, etc., is one of the strategies to minimize damage. Protected cultivation for vegetables has been recently studied by advanced and developing countries and have shown to be feasible and profitable (Tarannum et al 2014, Sreedhara et al 2013, Engindeniz \& Tuzel 2006, Polat et al 2005, Yadav et al 2014). In the Philippines particularly in Eastern Visayas, economics research combined with agronomic and engineering have been carried out to assess the functional and economic performance of a cost-effective, protected cropping structure for a 4 year period from 2008 to 2012 (Armenia et al 2013). Focus group discussions of farmer cooperators and field technicians were conducted. Results showed that protected cropping is economically feasible for skilled farmers who can provide appropriate inputs. Sweet pepper and ampalaya performed better giving an above average net gains in the protective structures and in the open field, but relatively higher within structures. In Leyte, Philippines, Gonzaga et al (2013) also evaluated the technical feasibility of growing vegetable crops under low-cost protected cropping structures. Thirty-four protected cropping structures were constructed at four sites; Visayas State University (VSU), Ormoc, Cabintan, Maasin and Bontoc. They found out that protected cropping structures are technically feasible during the wet and dry season for cauliflower, green onion, lettuce, chilli pepper, etc. and have higher average yield advantage than in the open field. Pest management practices are also recommended and further suggested that farmers' skills shoud be adequate to adopt the technology.

However, the adoption of protected cultivation is very minimal in Leyte. This is because investing in this technology involves high construction costs, uncertainty in financial gains and high risk in the occurence of harsh weather conditions that may destroy the structures (Seriño et al 2017). The uncertainties and risks associated with the region's weather conditions, constitutes adverse impacts, not only on the society and economy, but also to farmers as well. Will adopting protected cultivation enhance vegetable yields and profitability of farmers as compared to conventional farming? If protected cultivation entails huge initial investment costs, how can the farmers adopt this technology when they are financially constrained? How long can they recover the initial investment cost? Do the costs involved exceed the benefits to be gained? What if a strong typhoon comes and damages the crops and structures, how much will they be gaining then? There is really a great trade-off between protection and cost. This study therefore 
will assess the risks of investing and the profitability of protected cultivation considering the occurrence of harsh weather conditions.

This study was conducted in Baybay City, Leyte, a lowland area, and in Brgy Cabintan, an upland barangay in Ormoc City, Leyte to evaluate the profitability of protected cultivation as compared to open-field cultivation of vegetables, considering the occurrence of unfavourable weather conditions by incorporating risk in the financial analyses. Specifically, it aimed to: (1) determine the production cost (variable \& fixed cost) and the value of crops grown under different types of protective structures; (2) assess the profitability of protected vegetable cultivation associated with unfavourable weather conditions; (3) examine the changes of these measures of profitability with changes in price, cost, yield, and production costs; and (4) provide policy recommendations for the enhancement of adoption of protected vegetable cultivation under Leyte conditions.

The study was done by evaluating three (3) types of protective structures in Baybay City, and in Brgy. Cabintan, Ormoc City Leyte. The data gathered on protected and open field cultivation in the study sites were not the same and constituted management differences since this study was based on actual vegetable production of farmers and not on an experimental set-up. With limited data, focus group discussions with farmers and experts' opinions were used to gather the expected life span of each protective structure as well as potential yield changes of crops and structure damages incurred during extreme weather conditions. The calculations for the net present values (NPVs) and other financial indicators are subject to some assumptions which are based on current market conditions.

\section{METHODOLOGY}

\section{Data Collection}

Three types of protective structure designs for vegetable production were evaluated. A steel-type-high-strength-tunnel in Baybay City, Leyte and steel-typelow-tunnel and high-tunnel-structure in Brgy Cabintan, Ormoc City, Leyte. Data were obtained through face-to-face interviews with farmers using a survey questionnaire in Baybay site. In Brgy. Cabintan, Ormoc City, Leyte, a steel-type-low-tunnel and hightunnel structure was evaluated using secondary data from Australian Centre for International Agricultural Reasearch (ACIAR) Project - Value Chain Component. Data from open field cultivations in Cabintan site were also gathered, specifically, from farms planting tomatoes to compare it with crops planted under the protective structures. Data on open field cultivation served as comparison for protected cultivation. Information as to the potential yields and structure damages in case of adverse climatic conditions were gathered using Delphi technique where consensus from experts are considered.

\section{Data Analysis}

\section{Gross margin analysis}

Gross margin is the firm's total revenue minus the cost of goods sold or the variable inputs used to produce the outputs sold. The total revenue comprises the 
Investment appraisal and risk assessment of protected vegetable

sales from marketable and non-marketable yield of crops. Mathematically,

Gross Margin= Revenues - Variable Cost

\section{Cost-benefit Analysis using Financial Cash Flow}

A discounted financial cash flow was used to estimate the benefits and cost of investing into a protected cropping technology as compared with an open field cultivation. This was projected for 10 years. This included capital flows and operating flows where the former constituted capital outlays and inflows and the latter constituted project revenue and operating cost. Capital outlays were the cost of fixed assets such as the initial investment for the construction of the protective structure, the cost of tools, equipment and machinery required to build. As a guideline of ACIAR Economic Research Methods, the working capital of $2 \%$ was added to the project capital outlay. Allowance for asset retention was taken into account at the end of the project. It was assumed that the assets are valued as a capital inflow at the end of the project (Harrison \& Herbohn 2008).

Project revenue comprised the income or sales that were generated from the production of vegetables. Operating cost were the cost of labour, raw materials etc. Annual repair and maintenance of $5 \%$ of the structure cost as well as contingency cost of $2 \%$ from direct inputs, labor and overhead cost were taken into account.

In doing the cost-benefit analysis using a financial cashflow, a $15 \%$ discount rate was used since this was the currently recommended discount rate by the National Economic Development Authority (NEDA) to economically evaluate investment projects. The gross-sales of farmers at current conditions are not taxed. Based on the ACIAR guidelines for economic research methods, it is important to present a before-tax and an after-tax net cash flow, that is why a precentage tax rate of $3 \%$ was used for Baybay site and $5 \%$ in Cabintan site. A $3 \%$ tax in Baybay site since this was recommended by BIR (Bureau of Internal Revenue) on gross receipts of sale or lease of goods for those covered from the VAT exemptions Section 109. A tax rate of $5 \%$ was used in Cabintan site since the current produce when marketed to Gaisano Cebu paid this rate. As projected for 10 years, the crop rotation and selling price of these crops are the same per year.

A total of 3 scenarios (Scenario A-C) were considered for the cost-benefit analysis in this study (Table 1). Base Case Scenario (Scenario A) was a scenario without incorporating the risk of crop failure and structure damage associated with the occurrence of weather conditions and Scenario B (Tropical Cyclone or Typhoon). Scenario B was divided into three sub-scenarios representing the warning storm signals namely; Tropical Depression (Signal no. 1), Tropical Storm (Signal no. 2) and Typhoon and Super typhoon (Signal no. 3-5). These weather conditions were based on the fact that typhoons happen on an average of 20 times annually. Scenario $\mathrm{C}$ is strong wind phenomenon ("dumagsa") in Baybay City, Leyte with average speed of 205kph last January 23-25, 2017 which was not actually forecasted by PAGASA as a weather disturbance. In this study, it was assumed that the risky weather conditions will happen twice every 10 years. 
Table 1. Scenarios used in the study

\begin{tabular}{|c|c|c|c|c|c|}
\hline \multirow{2}{*}{ Cultivation } & \multirow{2}{*}{$\begin{array}{c}\text { Scenario A: Base } \\
\text { Case }\end{array}$} & \multicolumn{3}{|c|}{ Scenario B: Tropical Cyclone } & \multirow{2}{*}{$\begin{array}{c}\text { Scenario C: } \\
\text { Strong Wind } \\
\text { (Baybay site } \\
\text { only) }\end{array}$} \\
\hline & & Signal no. 1 & Signal no. 2 & Signal no. 3 & \\
\hline Protected & S1 & S2 & S3 & S4 & S5 \\
\hline Open Field & S6 & S7 & S8 & S9 & S10 \\
\hline
\end{tabular}

\section{Financial Indicators}

In valuing the net benefits, this was discounted to obtain the net present value. Mathematically, this was taken as:

$$
\text { Net Present Value }(N P V)=\frac{\sum \mathrm{B}_{\mathrm{t}}-\sum \mathrm{C}_{\mathrm{t}}}{(1+\mathrm{r})^{\mathrm{t}}} ; \mathrm{t}=1 \ldots \mathrm{n}
$$

wherein, $B_{t}$ was the benefits at time $t$, and $C_{t}$ was cost at time $t$ and $r$ is the discount rate. In determining the acceptability of the type of cultivation, the net present value should be positive which implied that the benefits exceeds the costs and explains that the project was profitable.

The Benefit-Cost Ratio (BCR) represented the ratio between the present value of benefits to the present value of costs. If the ratio is greater than 1 , the present value of benefits is greater than the costs, thus the investment would be acceptable in terms of economic efficiency. If the ratio was less than 1, it should be rejected. Mathematically,

$$
B C R=\frac{\frac{\mathrm{B}_{\mathrm{t}}}{(1+\mathrm{r})^{\mathrm{t}}}}{\frac{\mathrm{C}_{\mathrm{t}}}{(1+\mathrm{r})^{\mathrm{t}}}} ; \mathrm{t}=1 \ldots . \mathrm{n}
$$

Payback period (PP) was the number of years at which the company recovers its investment costs particularly when the net cash flow equals zero. The adaptation strategy that generated the shortest payback period will be more attractive and acceptable.

$$
\text { Payback Period }=\text { years full recovery }+\frac{\text { unrecovered cost at beginning of last year }}{\text { cash flow in last year }}
$$

\section{Expected Value Approach}

The expected value approach was the most common approach in valuing projects by calculating the project's expected value. This represents the risk analysis on protected cutivation. Payoff matrices was used to rank alternative adaptation strategies that were mutually exclusive. In calculating the expected value, the sum of the product of the probability of each possible scenario which was the incidence of tropical cyclones. Historical probabilities of the occurrence of tropical cyclones where calculated from the 2013 tropical cyclone tracks recorded by the Philippine Atmospheric, Geophysical and Astronomical Services Administration (PAG-ASA). 
Investment appraisal and risk assessment of protected vegetable

\section{RESULTS AND DISCUSSION}

\section{High Strength Tunnel}

\section{Structure cost and design}

The steel type protective structure called high-strength-tunnel in Brgy. Kilim, Baybay City, Leyte is covered with either net (Figure 1) or with polyethylene plastic (PEP) (Figure 2). Each structure (net-covered \& polyethylene-covered) had an area of $135 \mathrm{~m}^{2}$ and a height of $2 \mathrm{~m}$.

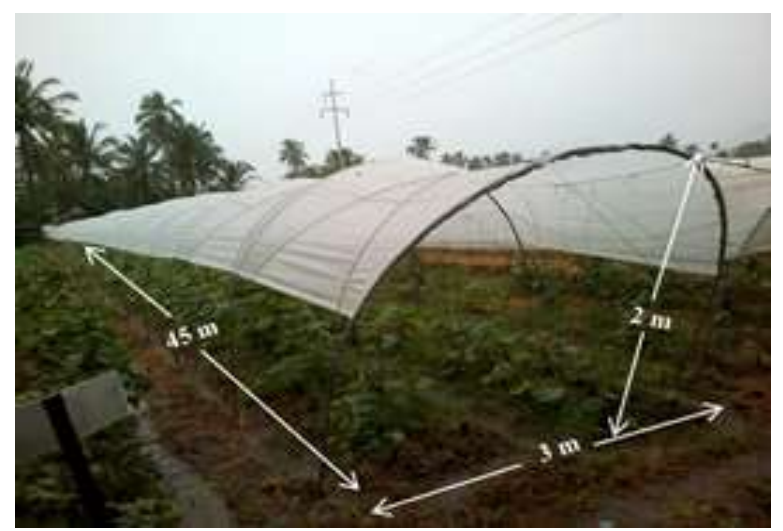

Figure 1. High-strength-tunnel covered with net

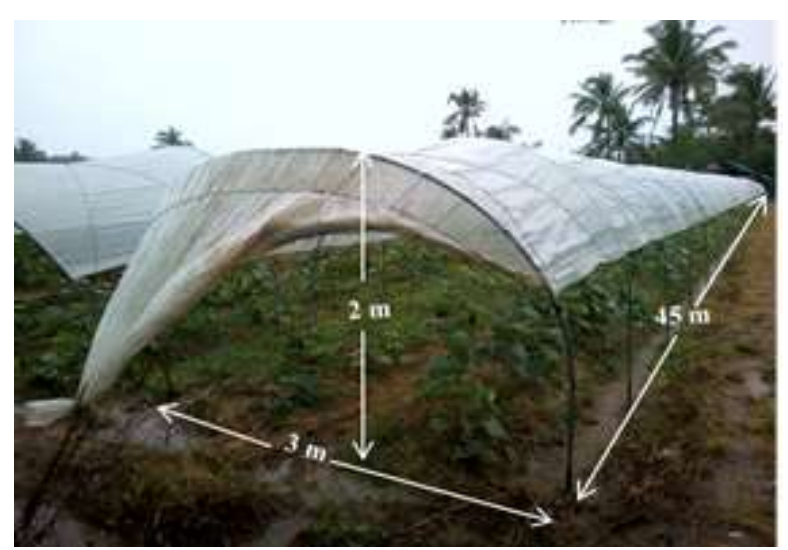

Figure 2. High-strength-tunnel covered with polyethylene plastic

The advantage of this tunnel type structure is its mobility. Its cover (net or plastic) can be removed easily during extreme wind and heat conditions given prior weather advisory. Removing its covering prevents the destruction of structure from strong winds. This will also avoid heat stress and build up of soil-borne diseases. The cost of building the structure is shown in Table 2. The UV filtered- 
net is more expensive than the UV filtered-plastic hence the plastic-covered-tunnel (PHP128.39 per $\mathrm{m}^{2}$ ) is relatively cheaper than the net-covered (PHP144.99 per $\mathrm{m}^{2}$ ). The protective structure has an estimated life span of 10 years.

Table2. Capital cost of materials for high-strength-tunnel covered with net and polyethylene plastic (in pesos)

\begin{tabular}{lrr}
\hline \multirow{2}{*}{ Materials/Description } & \multicolumn{2}{c}{ Total Cost } \\
\cline { 2 - 3 } & Net-Covered & Polyethylene-Covered \\
\hline G.I. Pipe (1 1/2") & $7,680.00$ & $7,680.00$ \\
UV Treated Covering & $8,991.00$ & $6,750.00$ \\
PP Twine (5 ply/black) & 810.00 & 810.00 \\
PP Twine (3 ply/black) & 405.00 & 405.00 \\
Nail (3" size) & 157.50 & 157.50 \\
Driller Rent & 450.00 & 450.00 \\
Labor (2 workers) & $1,080.00$ & $1,080.00$ \\
\hline Total (135m $\left.{ }^{2}\right)$ & $19,573.50$ & $17,332.50$ \\
\hline Total $\left(\right.$ per $\left.\mathrm{m}^{2}\right)$ & 144.99 & 128.39 \\
\hline
\end{tabular}

\section{Gross Margin}

The crops grown under high-strength-tunnel, either covered with net or polyethylene plastic (PEP) are cucumber, sweet pepper and string beans, while cucumber and string beans are also grown using the open field cultivation. One of the differences in protected and open field cultivation is in the water management. Protected cultivation employs furrow irrigation while open field uses manual irrigation (watering).

The high-strength-tunnel (HST) covered with PEP has higher gross margins for cucumber and string beans of PHP326.69 per $\mathrm{m}^{2}$ and PHP33.79 per $\mathrm{m}^{2}$, respectively, than the net-covered-tunnel and open field cultivation (Table 3 ). Although cucumber under both tunnels are sold at the same price of PHP30 per kg, higher yields are obtained under PEP-covered-tunnel with $12.3 \mathrm{~kg}$ per $\mathrm{m}^{2}$. This suggests that the PEP-covered-tunnel more effectively protects the growing crops from excessive rains whereas the net-covered-tunnel, still allows more rainwater to enter inside the structure than is optimal for the crop. Sweet pepper production under both tunnels obtain negative gross margins due to Phytophtora blight disease infection which causes severe wilting and death of plants. The open field cultivation has the lowest gross margins as compared with protected cultivation because yields are generally lower of $2.86 \mathrm{~kg} \mathrm{per} \mathrm{m}^{2}$ of cucumber and $0.97 \mathrm{~kg} \mathrm{per} \mathrm{m}^{2}$ of string beans. 
Investment appraisal and risk assessment of protected vegetable

Table 3. Gross margin of crops grown under high-strength-tunnel (HST) covered with net and PEP as compared with open field cultivation in Baybay (per $\mathrm{m}^{2}$ ) (in pesos)

\begin{tabular}{lrrrrr}
\hline & \multirow{2}{*}{ Receipts } & \multicolumn{3}{c}{ Variable Cost } & \multirow{2}{*}{ Gross } \\
\cline { 3 - 5 } & & Direct Inputs & Labor & Overhead Cost & Margin \\
\hline HST-Net & & & & & \\
$\quad$ Cucumber & 246.40 & 6.06 & 25.06 & 11.79 & 203.49 \\
$\quad$ Sweet Pepper & 19.56 & 23.88 & 9.65 & 1.60 & -15.58 \\
$\quad$ String Beans & 39.11 & 9.27 & 12.84 & 2.76 & 14.24 \\
HST-Polyethylene (PEP) & & & & & \\
$\quad$ Cucumber & 369.60 & 6.06 & 25.06 & 11.79 & 326.69 \\
$\quad$ Sweet Pepper & 29.33 & 23.88 & 9.65 & 1.60 & -5.80 \\
$\quad$ String Beans & 58.67 & 9.27 & 12.84 & 2.76 & 33.79 \\
Open Field & & & & & \\
$\quad$ Cucumber & 77.73 & 26.13 & 34.21 & 3.33 & 14.06 \\
$\quad$ String Beans & 51.70 & 13.15 & 23.13 & 1.39 & 14.04 \\
\hline
\end{tabular}

\section{Financial Analysis}

Base case scenario results in Table 4 reveal that the high-strength-tunnel covered with PEP, as projected for 10 years, generate the highest NPV of PHP1,440.58 and the lowest with the open field cultivation with PHP46.14. The protective structure has relatively higher NPV, although it involved huge investment cost, it generates higher revenues as compared with the open field. The open field has a positive NPV since its lower yield can offset its relatively lower initial investment cost which only involved a few farm tools already owned by the farmer. The BCR also implies that for every one peso invested, the plastic-covered-highstrength-tunnel can generate higher benefits equivalent up to PHP2.60 as compared with open field of PHP1.08 only. Earliest payback obtained by this structure is after 1 year.

Table 4. Summary of Base Case Scenario results of vegetable production grown under highstrength-tunnel-structure (both plastic- \& net-covered) and open field condition (per $\mathrm{m}^{2}$ ) (in pesos)

\begin{tabular}{lccc}
\hline & \multicolumn{3}{c}{ Base Case Scenario } \\
\cline { 2 - 2 } \multicolumn{1}{c}{ Performance Indicators } & \multicolumn{2}{c}{ High Strength Tunnel } & \\
\cline { 2 - 3 } & $\begin{array}{c}\text { Polyethylene } \\
\text { (PEP) }\end{array}$ & Net & \\
\hline After-Tax Net Present Value (NPV) & $1,440.58$ & 676.38 & 46.14 \\
Benefit-Cost Ratio (BCR) & 2.60 & 1.75 & 1.08 \\
Internal Rate of Return (IRR) & $143 \%$ & $72 \%$ & $44 \%$ \\
Payback Period & 1 year & 2 years & 3 years \\
\hline
\end{tabular}

By incorporating risk and assuming string beans production will be affected, given strong wind scenario, tropical cyclone signals no. 1, 2 , and 3-5, the PEPcovered-high-strength-tunnel generates the highest NPV across all scenarios (Table 5). Although, the structure needs to be reinstalled after every cyclone, the revenues generated, especially from cucumber, can effectively offset the initial investment cost. 
Ratilla \& Seriño

Table 5. Summary of net present values calculated for each kind of scenario under High Strength Tunnel and open field cultivation in Baybay site (per $\mathrm{m}^{2}$ ) (in pesos)

\begin{tabular}{|c|c|c|c|c|}
\hline \multirow{3}{*}{\multicolumn{2}{|c|}{ Scenarios ( $15 \%$ discount rate) }} & \multicolumn{3}{|c|}{ After-Tax Net Present Values } \\
\hline & & \multicolumn{2}{|c|}{ High Strength Tunnel } & \multirow{2}{*}{ Open Field } \\
\hline & & Plastic & Net & \\
\hline \multicolumn{2}{|c|}{ Base Case } & $1,440.58$ & 676.38 & 46.14 \\
\hline \multicolumn{2}{|c|}{ Strong Wind } & $1,403.72$ & 659.85 & 23.17 \\
\hline \multirow[t]{3}{*}{ Tropical Cyclone } & Signal no. 1 & $1,440.58$ & 671.87 & 34.43 \\
\hline & Signal no. 2 & $1,357.32$ & 594.19 & 14.15 \\
\hline & Signal no. 3-5 & $1,274.06$ & 511.99 & 5.14 \\
\hline
\end{tabular}

\section{Expected Value Approach}

Given tropical cyclone conditions, the high strength tunnel covered with polyethylene plastic (PEP) has the highest expected value of PHP1,336.50 per $\mathrm{m}^{2}$ than the net-covered tunnel and open field production (Table 6). This implies that this structure is the most viable and most preferred cultivation with regards to its current performance.

Table6. Pay- off matrices of net present values under High Strength Tunnel and open field cultivation options and tropical cyclone conditions in Baybay Site $\left(\right.$ per $^{2}$ ) (in pesos)

\begin{tabular}{|c|c|c|c|c|}
\hline \multirow[b]{2}{*}{ Options } & \multicolumn{3}{|c|}{ Tropical Cyclone } & \multirow[b]{2}{*}{$\begin{array}{l}\text { Expected } \\
\text { Value }\end{array}$} \\
\hline & Signal No. 1 & Signal No. 2 & $\begin{array}{c}\text { Signal No. 3- } \\
5 \\
\end{array}$ & \\
\hline Probability & 0.25 & 0.25 & 0.50 & \\
\hline HST_Plastic (PEP) & $1,440.58$ & $1,357.32$ & $1,274.06$ & $1,336.50$ \\
\hline HST_Net & 671.87 & 594.19 & 511.99 & 572.51 \\
\hline Open Field & 34.43 & 14.15 & 5.14 & 14.72 \\
\hline
\end{tabular}

\section{Low Tunnel and High Tunnel Structure}

A low-tunnel and high-tunnel-structure are evaluated in Brgy. Cabintan, Ormoc City, Leyte. These structures were given as a grant to Cabintan Livelihood Community Association (CALCOA) by the Australian Center for International Agricultural Research (ACIAR). Although this structure was given for free, the establishment cost of each structure was taken into account to determine the profitability and viability of the investment.

\section{Structure Design and Cost}

The establishment cost of low-tunnel-structure (Figure 3) covered with UV treated plastic is PHP31,585. It has a height of $1.5 \mathrm{~m}$ and an available area of 150 square meters. Converting this to per $\mathrm{m}^{2}$, this structure had an establishment cost of PHP210.57 per $\mathrm{m}^{2}$ with an expected life span of 5 years as reported by a local expert.

The high-tunnel with an area $264 \mathrm{~m}^{2}$ and height of $2 \mathrm{~m}$ has a total cost of PHP61,201.67 (231.82per $\mathrm{m}^{2}$ ) (Figure 4). This structure has a UV filtered polyethylene plastic covering where its bottom is buried into the ground. This has expected life span of approximately 10-15 years. The estimated life span of these structures are still subject to changes in the future. 
Investment appraisal and risk assessment of protected vegetable

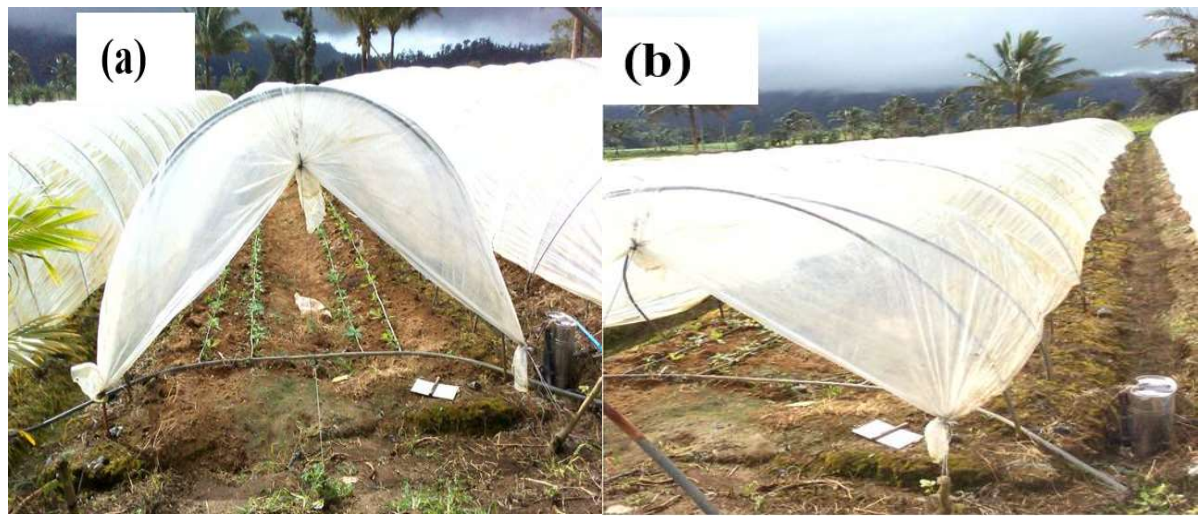

Figure 3. Front view (a) and side view (b) of the Low Tunnel covered with UV-treated plastic

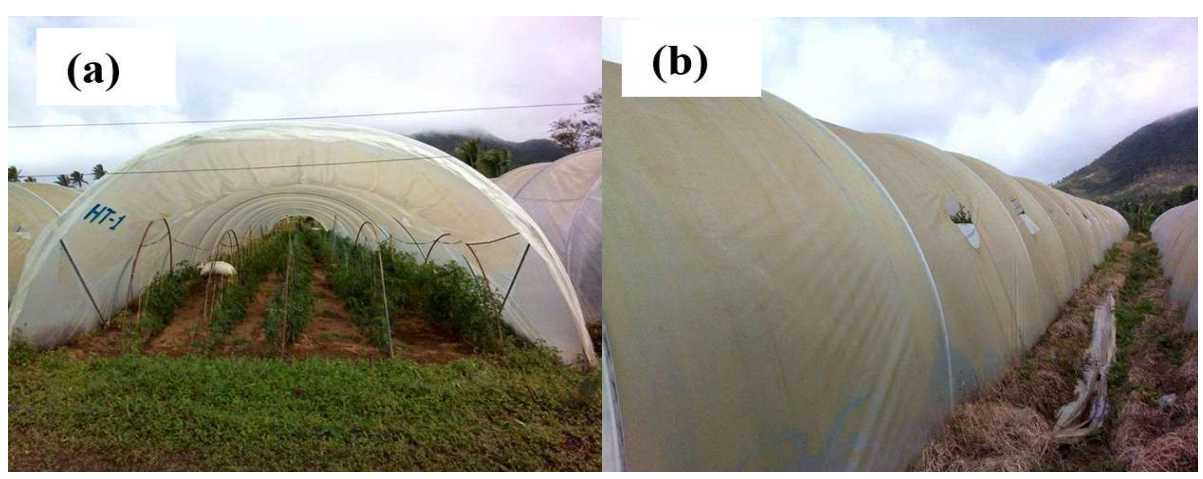

Figure 4. Front view (a) and side view (b) of the High Tunnel with UV-treated plastic

\section{Gross Margin Per Crop}

Tomatoes have been planted in this protective structure since the structure's establishment. The apparent difference between the protected and open field cultivation is with water management, market outlet and area planted. The protected cultivation has a drip irrigation system; while, the open field-cultivation is rainfed and employs manual watering. Produce from protected cultivation are mostly sold in Cebu particularly in Metro Gaisano and a few in the local market. The market linkage to Cebu Metro Gaisano is made possible with the help of the ACIARValue Chain Component Project. With the open field cultivation, a middleman markets their products. With these, prices offered for protected and open field cultivation differ. This is because vegetables grown under protected cultivation had higher quality; thus capturing higher prices. The vegetables were graded by size (small, medium, large, extra large) and the Cebu market quality standards. There were additional costs for marketing and transportation to access the Cebu market but, the high price given offset these costs. They also differ in terms of area planted. That is, open field cultivations have relatively larger area compared to protected cultivation. 


\section{Low Tunnel Structure}

Since the reinstallation of the low-tunnel after destructive Typhoon Yolanda, only one cropping of tomato under low-tunnel-structure is recorded. As shown in Table 7, the low-tunnel generates a higher gross margin of PHP118.56 per $\mathrm{m}^{2}$ for tomato as compared with open field. This is because a higher yield is obtained under low-tunnel production of $4.98 \mathrm{~kg}$ per $\mathrm{m}^{2}$ than open field yields of 1.63 (first cropping) and $1.24 \mathrm{~kg}$ per $\mathrm{m}^{2}$ (second cropping) only. Higher price is also captured for the produce under low-tunnel production of PHP38.22 per kg on average compared with the open field price of only PHP20.00 (first cropping) and PHP25.00 per kg (second cropping). Chinese cabbage production in the open field failed and was terminated early due to heavy rainfall.

Table 7. Gross margin of enterprise grown under low-tunnel as compared with open field (in pesos) $\left(\right.$ perm $\left.\mathrm{m}^{2}\right)$

\begin{tabular}{lrrrrrrr}
\hline \multirow{2}{*}{ Production } & Receipts & $\begin{array}{c}\text { Direct } \\
\text { Inputs }\end{array}$ & Labor & Marketing & Overhead & \multirow{2}{*}{$\begin{array}{c}\text { Gross } \\
\text { Margin }\end{array}$} \\
\cline { 3 - 6 } & & & & & & \\
Low Tunnel & 190.29 & 6.02 & 34.36 & 29.22 & 2.13 & 118.56 \\
Tomato & & & & & & \\
\hline Open Field & 32.69 & 3.55 & 8.09 & - & 0.14 & 20.91 \\
Tomato & 3.55 & 2.77 & 4.59 & - & 0.14 & -3.95 \\
Chinese Cabbage & 30.98 & 3.58 & 5.31 & - & 0.07 & 22.02 \\
Tomato & & & & & & \\
\hline
\end{tabular}

\section{High Tunnel Structure}

Table 8 shows the gross margins of high-tunnel and open field cultivation. Data indicates that sweet pepper obtained the highest gross margin of PHP74.69 per $\mathrm{m}^{2}$ and lowest by lettuce production (PHP8.12 per $\mathrm{m}^{2}$ ) under high-tunnel cultivation. Comparing the gross margin of tomato grown under both cultivations, if ranked, the tomato production under the protective structure $\left(1^{\text {st }} \& 2^{\text {nd }}\right.$ cropping $)$ generated higher gross margins of PHP54.07 per $\mathrm{m}^{2}$ and PHP52.59 per $\mathrm{m}^{2}$ compared to an open field production of PHP12.65 per $\mathrm{m}^{2}$ and PHP1.64 per $\mathrm{m}^{2}$, respectively. The highest yields and selling price were obtained with the high-tunnel production compared to open field production. On one hand, the first cropping and second cropping of tomato under protective structure have yields of 4.04 and $2.34 \mathrm{~kg} \mathrm{per} \mathrm{m}^{2}$, and sold at PHP25.51 and PHP32.40 per kg, respectively. On the other hand, open field tomato yielded $0.28 \mathrm{~kg}$ per $\mathrm{m}^{2}$ for first cropping and $0.88 \mathrm{~kg}$ per $\mathrm{m}^{2}$ for second cropping and sold at an average of PHP15.00 per $\mathrm{kg}$ and PHP18.75 per $\mathrm{kg}$, respectively. 
Investment appraisal and risk assessment of protected vegetable

Table 8. Gross margin of enterprise grown under high-tunnel as compared with open field (in pesos) $\left(\right.$ per $\left.\mathrm{m}^{2}\right)$

\begin{tabular}{|c|c|c|c|c|c|c|}
\hline \multirow{2}{*}{ Production } & \multirow{2}{*}{ Receipts } & \multicolumn{4}{|c|}{ Variable Cost } & \multirow{2}{*}{$\begin{array}{l}\text { Gross } \\
\text { Margin }\end{array}$} \\
\hline & & Direct Inputs & Labor & Marketing & Overhead & \\
\hline \multicolumn{7}{|l|}{ High Tunnel } \\
\hline Tomato (1st) & 103.08 & 7.91 & 17.94 & 20.74 & 2.42 & 54.07 \\
\hline Tomato (2nd) & 75.74 & 5.47 & 7.52 & 9.55 & 0.61 & 52.59 \\
\hline Lettuce & 16.50 & 2.00 & 4.92 & 0.85 & 0.61 & 8.12 \\
\hline Sweet Pepper & 107.36 & 36.71 & 10.64 & 3.24 & 1.36 & 55.41 \\
\hline \multicolumn{7}{|l|}{ Open Field } \\
\hline Tomato (1st) & 4.13 & 7.08 & 8.69 & - & 1.00 & -12.65 \\
\hline Tomato (2nd) & 16.91 & 7.08 & 7.19 & - & 1.00 & 1.64 \\
\hline Cabbage & 42.43 & 8.47 & 6.94 & - & 1.00 & 26.02 \\
\hline
\end{tabular}

The first cropping of tomato under open-field conditions was a failure due to dry conditions, requiring frequent watering, entailing higher labor cost and reducing yield which resulted to a negative grosss margin.

\section{Financial Analysis}

In this section, current set-up or current market pertains to the current situation of CALCOA farmers of simultaneously selling the produce in Cebu market and Ormoc (local) market. With the same quality of produce, two markets were involved because some harvests are not large enough thus marketed to the local market, instead of marketing it to Cebu which will entail higher marketing cost per unit. Cebu market pertains to a scenario wherein all the produce is sold in Cebu Gaisano, a high-end market. Local market describes another scenario of selling the entire produce in Ormoc market, the nearest local market. For open field cultivation, the produce is picked up from the farm and sold to middlemen.

\section{Low Tunnel}

The results of the 10-year projection with Base Case scenario (risk not yet incorporated), reveals that two (2) croppings of tomato in one (1) year under lowtunnel with Cebu as primary market generated the highest NPV (PHP449.57 per $\mathrm{m}^{2}$ ) relative to the local market scenario (Table 9). It also obtained the highest BCR and IRR of 1.26 , and $36 \%$, respectively. This means that for every 1 peso invested in a low-tunnel-structure, the farmer can get PHP1.26 per $\mathrm{m}^{2}$. It also has the earliest payback period, 4 years, as compared with the current-set-up and local-market scenario. The open field cultivation with two croppings of tomato and a cropping of chinese cabbage, generated a positive NPV of PHP51.83 per $\mathrm{m}^{2}$ and BCR of 1.18 , which was still relatively low compared with all the scenarios in the protected cultivation. 
Table 9. Base case scenario results for the low-tunnel structure as compared with open field cultivation (per $\mathrm{m}^{2}$ ) (in pesos)

\begin{tabular}{lccrrr}
\hline & \multicolumn{3}{c}{ Base Case Scenario } & \multirow{2}{*}{ Open } \\
\cline { 2 - 4 } \multicolumn{1}{c}{ Performance Indicators } & Current Set Up & $\begin{array}{c}\text { Cebu } \\
\text { Market }\end{array}$ & Local Market & Field \\
\cline { 2 - 4 } & 281.76 & 449.57 & 216.34 & 51.83 \\
After-Tax Net Present Value & 1.17 & 1.26 & 1.16 & 1.18 \\
Benefit-Cost Ratio (BCR) & $29 \%$ & $36 \%$ & $26 \%$ & $39 \%$ \\
Internal Rate of Return (IRR) & 4 years & 4 years & 5 years & 4 years \\
Payback Period & & & & \\
\hline
\end{tabular}

Financial analysis across tropical cyclone scenarios (Signal no. 1, 2, \& 3-5) shows that for the low-tunnel-structure, accessing the Cebu market is the most viable investment (Table 10). The low-tunnel-structure generated the highest NPVs because of the higher prices captured in the Cebu market, which increases revenues and recovers initial investment costs more effectively. Its payback period is 5 years if affected with tropical cyclone signals no. 2, and 7 years if affected with signal no. 3-5. With the signal no. 3-5 scenario, the low-tunnel-structure will be totally destroyed as was experienced by farmers during the Supertyphoon Yolanda (Haian) on November 2013. These conditions totally destroyed all open field production as well. However, calculations indicated that if the entire production from low-tunnel-structure is sold entirely in Cebu, a positive NPV of PHP82.86 per $\mathrm{m}^{2}$, and greater than $1 \mathrm{BCR}$ of 1.04 can still be generated even with signal no. 3 to 5 . It is important to note that in this signal no. 3-5 scenario, only one cropping of tomato is affected in a year. Thus, farmers still generated income from their previous cropping in that year. This ranked highest as compared with other market scenarios and open field cultivations. Payback period then becomes 7 years, whereas payback period for the open field production is 5 years. Sensitivity analysis has shown that increasing selling price in Cebu market from PHP41.75 to PHP50.10 per $\mathrm{kg}$ can generate higher NPVs of PHP443.84 per $\mathrm{m}^{2}$ with signal no. 3-5 scenario.

Table 10. Summary of net present values calculated for three cyclone scenarios for low-tunnel tomato production in Cabintan Site (per $\mathrm{m}^{2}$ ) (in pesos)

\begin{tabular}{|c|c|c|c|c|c|}
\hline \multirow{3}{*}{\multicolumn{2}{|c|}{ Scenarios ( $15 \%$ discount rate) }} & \multicolumn{4}{|c|}{ After-Tax Net Present Value } \\
\hline & & \multicolumn{3}{|c|}{ Low Tunnel } & \multirow{2}{*}{ Open Field } \\
\hline & & Current Market & Cebu Market & Local Market & \\
\hline \multicolumn{2}{|c|}{ Base Case } & 281.76 & 449.57 & 216.34 & 51.83 \\
\hline Tropical & Signal no. 1 & 281.76 & 449.57 & 216.34 & 36.85 \\
\hline \multirow{2}{*}{ Cyclone } & Signal no. 2 & 81.55 & 239.59 & 37.35 & 31.11 \\
\hline & Signal no. 3-5 & -69.92 & 82.86 & -102.70 & 25.38 \\
\hline
\end{tabular}

However, investing in a low-tunnel-structure and selling the entire produce in the local market is not feasible across all climatic scenarios. Sensitivity analysis where the selling price of tomatoes grown under low-tunnel is the same as open field produced at PHP20.00 per kg, shows that negative NPVs are generated across all scenarios (Table 11). At this price per $\mathrm{kg}$, the low-tunnel-structure will not be a viable investment. 
Investment appraisal and risk assessment of protected vegetable

Table 11. Sensitivity analysis for a low-tunnel-structure as compared with open field cultivation when the selling price of tomatoes are equivalent (in pesos) $\left(\right.$ per $\left.^{2}\right)$

\begin{tabular}{cccc}
\hline \multirow{2}{*}{ Scenarios (15\% discount rate) } & \multicolumn{2}{c}{ After-Tax Net Present Value } \\
\cline { 2 - 4 } & \multicolumn{2}{c}{ Tow Tunnel } & Open Field \\
\hline \multicolumn{2}{c}{ Tomato Price (Php/kg) } & 20.00 & 20.00 \\
Base Case & -583.18 & 51.83 \\
\multirow{2}{*}{ Tropical Cyclone } & Signal no. 1 & -583.18 & 36.85 \\
& Signal no. 2 & -733.05 & 31.11 \\
& Signal no. 3-5 & -857.42 & 25.38 \\
\hline
\end{tabular}

It is only viable to invest in a low-tunnel-structure when a high-end market is available to sell the produce. This market offers higher prices which generates more revenues and thus increasing profit to effectively offset the initial investment cost. Thus, market outlet is one of the critical factors that affect profitability and pricing.

\section{High Tunnel Structure}

Three crop types (tomato, lettuce \& sweet pepper) were planted in high-tunnelstructures, and three financial analyses projected for 10 years were done assuming three different crop rotations for one (1) year. These rotations include: two croppings of tomato (based on actual data) for which each cropping lasts for 4.3 months; two croppings of tomato and one cropping of lettuce production (2 months); and one cropping of tomato plus one cropping of sweet pepper production sweet( 6 months).

Base case scenario results reveal that growing two croppings of tomato, or two croppings of tomato + one cropping of lettuce, or a cropping of sweet pepper and tomato in high-tunnel obtain negative NPVs under the current set up of simultaneously having two markets and local markets as well in the open field. However, selling the entire produce at Cebu market prices two croppings of tomato and a cropping of lettuce will generate a positive NPV of PHP272.54 per $\mathrm{m}^{2}$. It also generates a BCR, IRR and earliest payback period of $1.25,28 \%$ and 5 years, respectively (Table 12). The open field production generates a negative NPV with its' production of two croppings of tomato and cabbage because of a failed tomato production due to extreme heat. It can be said that without incorporating risk, the production of two croppings of tomato + one cropping of lettuce under high-tunnel with Cebu market is the most viable option.

By incorporating risk of crop failure and structure damage associated with the occurrence of tropical cyclones (Signals 1, 2\& 3-5), the high-tunnel cultivation of two croppings tomato + one cropping of lettuce at Cebu market prices will attain a positive NPV for tropical cyclone signals 1 and 2 but not for signal no. 3-5 only (PHP6.81 per $\mathrm{m}^{2}$ ) (Table 13). This is because in the 10-year life of the project, the structure will need to be rebuilt twice (every 3 years) incurring the additional investment costs. With this, the production cannot offset the cost of reinstallation. However, sensitivity analysis shows that it will become positive if discount rates are lower at $1 \%-14 \%$. If given $15 \%$ discount rate, the production can generate a positive NPV per $\mathrm{m}^{2}$ of PHP208.41 or PHP337. 54. If tomatoes can be sold at $20 \%$ higher selling price for both croppings (ie, for $1^{\text {st }}$ cropping- PHP38.96 per kg to PHP46.75 per $\mathrm{kg} \&$ for $2^{\text {nd }}$ cropping- PHP35.59 per kg to PHP42.71 per kg) positive NPVs can be obtained. Capturing a higher selling price for lettuce by $200 \%$ (from PHP97.50 to PHP199.88), or simultaneously increasing yield $(10 \%)$ and price $(200 \%)$ can also generate a positive NPV per $\mathrm{m}^{2}$ of PHP82.67 or PHP100.14, respectively. 
Ratilla \& Seriño

Table 12. Base Case scenario results of high-tunnel-structure with different crop rotations as compared with open field cultivation (in pesos) $\left(\right.$ per $^{2}$ )

\begin{tabular}{|c|c|c|c|c|}
\hline \multicolumn{5}{|c|}{ Base Case Scenario } \\
\hline \multirow[b]{2}{*}{ Performance Indicators } & \multicolumn{3}{|c|}{ High Tunnel } & \multirow[b]{2}{*}{ Open Field } \\
\hline & $\begin{array}{l}\text { Current } \\
\text { Set Up }\end{array}$ & $\begin{array}{c}\text { Cebu } \\
\text { Market }\end{array}$ & $\begin{array}{l}\text { Local } \\
\text { Market }\end{array}$ & \\
\hline 2 Tomato & & & & $\begin{array}{c}2 \text { Tomato+ } 1 \\
\text { Cabbage }\end{array}$ \\
\hline After-Tax Net Present Value (NPV) & -64.36 & 230.20 & -149.26 & -31.02 \\
\hline Benefit-Cost Ratio (BCR) & 0.94 & 1.22 & 0.83 & 0.91 \\
\hline Internal Rate of Return (IRR) & $12 \%$ & $26 \%$ & $7 \%$ & - \\
\hline Return on Investment (ROI) & $20 \%$ & $33 \%$ & $16 \%$ & $-14 \%$ \\
\hline Payback Period & - & 7 years & - & - \\
\hline 2 Tomato + Lettuce & & & & $\begin{array}{c}2 \text { Tomato+ } 1 \\
\text { Cabbage }\end{array}$ \\
\hline After-Tax Net Present Value (NPV) & -20.73 & 272.54 & -102.59 & -31.02 \\
\hline Benefit-Cost Ratio (BCR) & 0.98 & 1.25 & 0.89 & 0.91 \\
\hline Internal Rate of Return (IRR) & $14 \%$ & $28 \%$ & $10 \%$ & - \\
\hline Return on Investment (ROI) & $22 \%$ & $35 \%$ & $18 \%$ & $-14 \%$ \\
\hline Payback Period & - & 5 years & - & - \\
\hline 1 Tomato + 1 Sweet Pepper & & & & $\begin{array}{c}2 \text { Tomato+ } 1 \\
\text { Cabbage }\end{array}$ \\
\hline After-Tax Net Present Value (NPV) & -39.88 & 221.88 & -8.58 & -31.02 \\
\hline Benefit-Cost Ratio (BCR) & 0.97 & 1.19 & 0.99 & 0.91 \\
\hline Internal Rate of Return (IRR) & $13 \%$ & $26 \%$ & $15 \%$ & - \\
\hline Return on Investment (ROI) & $21 \%$ & $33 \%$ & $23 \%$ & $-14 \%$ \\
\hline Payback Period & & 7 years & - & - \\
\hline
\end{tabular}

Table 13. Summary of net present values for different crop rotations calculated for each kind of

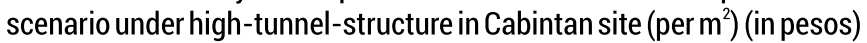

\begin{tabular}{|c|c|c|c|c|c|}
\hline \multirow{2}{*}{\multicolumn{2}{|c|}{ Performance Indicators }} & \multicolumn{3}{|c|}{ High Tunnel } & \multirow[b]{2}{*}{ Open Field } \\
\hline & & \multirow[t]{2}{*}{ Current Set Up } & $\begin{array}{c}\text { Cebu } \\
\text { Market }\end{array}$ & $\begin{array}{l}\text { Local } \\
\text { Market }\end{array}$ & \\
\hline \multicolumn{2}{|c|}{2 Tomato } & & & & $\begin{array}{c}2 \text { Tomato+ } 1 \\
\text { Cabbage }\end{array}$ \\
\hline \multicolumn{2}{|c|}{ Base Case } & -64.36 & 230.20 & -149.26 & -31.02 \\
\hline \multirow{3}{*}{$\begin{array}{l}\text { Tropical } \\
\text { Cyclone }\end{array}$} & Signal no. 1 & -64.36 & 230.20 & -149.26 & -39.21 \\
\hline & Signal no. 2 & -115.01 & 177.64 & -193.51 & -42.33 \\
\hline & Signal no. 3-5 & -337.35 & -49.15 & -400.92 & -45.46 \\
\hline \multicolumn{2}{|c|}{2 Tomato + Lettuce } & & & & $\begin{array}{c}2 \text { Tomato+ } 1 \\
\text { Cabbage }\end{array}$ \\
\hline \multicolumn{2}{|c|}{ Base Case } & -20.73 & 272.54 & -102.59 & -31.02 \\
\hline \multirow{3}{*}{$\begin{array}{l}\text { Tropical } \\
\text { Cyclone }\end{array}$} & Signal no. 1 & -20.73 & 272.54 & -102.59 & -39.21 \\
\hline & Signal no. 2 & -71.38 & 219.98 & -146.84 & -42.33 \\
\hline & Signal no. 3-5 & -293.72 & -6.81 & -354.26 & -45.46 \\
\hline \multicolumn{2}{|c|}{1 Tomato + 1 Sweet Pepper } & & & & $\begin{array}{c}2 \text { Tomato }+1 \\
\text { Cabbage }\end{array}$ \\
\hline \multicolumn{2}{|c|}{ Base Case } & -39.88 & 221.88 & -8.58 & -31.02 \\
\hline \multirow{3}{*}{$\begin{array}{l}\text { Tropical } \\
\text { Cyclone }\end{array}$} & Signal no. 1 & -39.88 & 221.88 & -8.58 & -39.21 \\
\hline & Signal no. 2 & -134.03 & 94.58 & -109.35 & -42.33 \\
\hline & Signal no. 3-5 & -338.06 & -123.67 & -316.22 & -45.46 \\
\hline
\end{tabular}


Investment appraisal and risk assessment of protected vegetable

The tomato and sweet pepper production under high-tunnel going to the Cebu market, obtains negative NPVs during typhoon signal no. 3-5 with PHP-123.67 per $\mathrm{m}^{2}$. Sweet pepper has high production costs since crop maintenance runs for 6 months. Sensitivity analysis with varying discount rates reveal that this production rotation selling in the Cebu market can obtain positive NPVs in all scenarios at $1 \%$ $7 \%$. A simultaneous increase in the price by $20 \%$ (PHP210.00 per kilo to PHP252.00 per kilo) and yield by $10 \%\left(0.51 \mathrm{~kg}\right.$ per $\mathrm{m}^{2}$ to $0.56 \mathrm{~kg}$ per $\left.\mathrm{m}^{2}\right)$ can also generate a positive NPV with this rotation across all scenarios.

With the three rotation scenarios in high-tunnel, the two croppings of tomato with lettuce generated the highest NPV making it as the most viable crop production. It is good to note that the volume of lettuce in this production is low. According to the farmers interviewed, lettuce in this production served as a trial if it is indeed suitable under high-tunnel. With this, lettuce production volume should be increased. The current set up of selling the produce simultaneously in two markets resulted to be not viable as well as selling the entire produce in local markets. Clearly profits are greatest if a high end market can be supplied. There should also be an increased production in sweet pepper since this is a high-valued crop and can capture high prices (ranges from PHP100-200 per kg) especially in high-end markets. However, the production of two croppings of tomato, and one cropping tomato + one cropping of sweet pepper for a year is not recommended since both crops are Solanaceous and producing crops consecutively from the same family can lead to increases in insect pest and disease pressure resulting in reduced yields in subsequent crops.

If tomatoes grown under high-tunnel-structure cannot sell at higher prices than field grown tomatoes then the structure is not viable. Sensitivity analysis where tomato is sold at PHP15.00 per kg for first cropping and PHP18.75 per kg for second cropping which is the same as the selling price for open field tomato reveals that the three crop rotations will generate negative NPVs across all scenarios (Table 14). Indicating that the selling price of the produce is one of the critical factors that can affect the viability of the investment. A higher selling price needs to be able to be captured when investing into a high-tunnel structure and other protective structures.

Table 14. Sensitivity analysis for high-tunnel-structure as compared with open field cultivation where selling price of tomato produced are the same (in pesos) $\left(\right.$ per $\left.\mathrm{m}^{2}\right)$

\begin{tabular}{|c|c|c|c|c|c|}
\hline \multirow{3}{*}{\multicolumn{2}{|c|}{ Scenarios ( $15 \%$ discount rate) }} & \multicolumn{4}{|c|}{ After-Tax Net Present Value } \\
\hline & & \multicolumn{3}{|c|}{ High Tunnel } & \multirow[b]{2}{*}{$\begin{array}{l}\text { Open Field } \\
\text { (2 Tomato+ } 1 \\
\text { Cabbage) }\end{array}$} \\
\hline & & 2 Tomato & $\begin{array}{c}2 \text { Tomato + } 1 \\
\text { Lettuce }\end{array}$ & $\begin{array}{c}1 \text { Tomato }+1 \\
\text { Sweet } \\
\text { Pepper }\end{array}$ & \\
\hline \multirow{3}{*}{\multicolumn{2}{|c|}{$\begin{array}{l}\text { Tomato Price (1st) (Php/kg) } \\
\text { Tomato Price (2nd) (Php/kg) } \\
\text { Base Case }\end{array}$}} & 15.00 & 15.00 & 15.00 & 15.00 \\
\hline & & 18.75 & 18.75 & - & 18.75 \\
\hline & & -418.99 & -376.65 & -249.36 & 18.16 \\
\hline \multirow{3}{*}{$\begin{array}{l}\text { Tropical } \\
\text { Cyclone }\end{array}$} & Signal no. 1 & -418.99 & -376.65 & -249.36 & 9.07 \\
\hline & Signal no. 2 & -461.46 & -419.13 & -317.60 & 5.60 \\
\hline & Signal no. 3-5 & -664.74 & -622.40 & -510.53 & 2.12 \\
\hline
\end{tabular}


Ratilla \& Seriño

\section{Expected Value Approach}

\section{Low tunnel structure}

For low-tunnel, the maximum expected value is attained with Cebu as the primary market (PHP213.72 per $\mathrm{m}^{2}$ ) under tropical cyclone conditions (Table 15). This is because it captured higher market prices at an average of PHP41.75 per kilogram (kg) unlike the PHP30.54 per kilogram average price offered in the local market. In this case, the low-tunnel investment with Cebu market is the preferred option.

Table 15. Pay-off matrices of net present values under different cultivation options and tropical cylone conditions (per $\mathrm{m}^{2}$ ) (in pesos)

\begin{tabular}{lcccc}
\hline \multirow{2}{*}{ Options } & \multicolumn{3}{c}{ Tropical Cyclone } & \multirow{2}{*}{$\begin{array}{c}\text { Expected } \\
\text { Value }\end{array}$} \\
\cline { 2 - 4 } & Signal No. & Signal No. & Signal No. 3- & Value \\
\hline Probability & 1 & 2 & 5 & \\
Low Tunnel (Current Set Up) & 0.25 & 0.25 & 0.5 & \\
Low Tunnel (Cebu Market) & 281.76 & 81.55 & $(69.92)$ & 55.87 \\
Low Tunnel (Local Market) & 449.57 & 239.59 & 82.86 & 213.72 \\
Open Field & 216.34 & 37.35 & $(102.70)$ & 12.08 \\
\hline
\end{tabular}

\section{High tunnel structure}

Under high-tunnel production, two croppings of tomato and one cropping of lettuce marketing in Cebu is the best option, given the high expected value in times

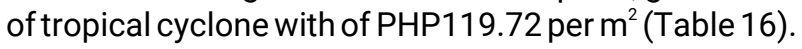

Table 16. Pay-off matrices of net present values under high-tunnel as compared with open field conditions and tropical cyclone conditions (per $\mathrm{m}^{2}$ ) (in pesos)

\begin{tabular}{|c|c|c|c|c|}
\hline \multirow[b]{2}{*}{ Options } & \multicolumn{3}{|c|}{ Tropical Cyclone } & \multirow{2}{*}{$\begin{array}{l}\text { Expected } \\
\text { Value }\end{array}$} \\
\hline & $\begin{array}{c}\text { Signal No. } \\
1\end{array}$ & $\begin{array}{c}\text { Signal No. } \\
2\end{array}$ & $\begin{array}{c}\text { Signal No. } \\
3-5\end{array}$ & \\
\hline Probability & 0.25 & 0.25 & 0.50 & \\
\hline Current Set-Up (2 Tomato) & -64.36 & -115.01 & -337.35 & -213.51 \\
\hline Current Set-Up (2 Tomato + Lettuce) & -20.73 & -71.38 & -293.72 & -169.89 \\
\hline Current Set-Up (Tomato + Sweet Pepper) & -39.88 & -134.03 & -338.06 & -212.51 \\
\hline Cebu Market (2 Tomato) & 230.20 & 177.64 & -49.15 & 77.39 \\
\hline Cebu Market (2 Tomato + Lettuce) & 272.54 & 219.98 & -6.81 & 119.72 \\
\hline Cebu Market (Tomato + Sweet Pepper) & 221.88 & 94.58 & -123.67 & 17.28 \\
\hline Local Market (2 Tomato) & -149.26 & -193.51 & -400.92 & -286.16 \\
\hline Local Market (2 Tomato + Lettuce) & -102.59 & -146.84 & -354.26 & -239.49 \\
\hline Local Market (Tomato + Sweet Pepper) & -8.58 & -109.35 & -316.22 & -187.59 \\
\hline Open Field & -39.21 & -42.33 & -45.46 & -43.12 \\
\hline
\end{tabular}

\section{Comparison of Low Tunnel and High Tunnel}

Based on expected values in Cabintan the low-tunnel-structure (PHP213.72 per $\mathrm{m}^{2}$ ) is more profitable than high-tunnel structure when selling in the Cebu market with risk of tropical cyclone conditions (Table 17). 
Investment appraisal and risk assessment of protected vegetable

Table 17. Comparison of expected values across protective structures in Cabintan site (per $\mathrm{m}^{2}$ ) (in pesos) with risk of tropical cyclone averaged across three cyclone intensity scenarios

\begin{tabular}{lr}
\hline \multicolumn{1}{c}{ Options } & Expected Value \\
\cline { 2 - 2 } Low Tunnel (Current Set-Up) & Tropical Cyclone \\
Low Tunnel (Cebu Market) & 55.87 \\
Low Tunnel (Local Market) & 213.72 \\
High Tunnel_Current Set-Up (2 Tomato) & 12.08 \\
High Tunnel_Current Set-Up (2 Tomato+ Lettuce) & -213.51 \\
High Tunnel_Current Set-Up (Tomato + Sweet Pepper) & -169.89 \\
High Tunnel_Cebu Market (2 Tomato) & -212.51 \\
High Tunnel_Cebu Market (2 Tomato+ Lettuce) & 77.39 \\
High Tunnel_Cebu Market (Tomato + Sweet Pepper) & 119.72 \\
High Tunnel_Local Market (2 Tomato) & 17.28 \\
High Tunnel_Local Market (2 Tomato + Lettuce) & -286.16 \\
High Tunnel_Local Market (Tomato + Sweet Pepper) & -239.49 \\
\hline
\end{tabular}

\section{CONCLUSIONS ANDPOLICY IMPLICATIONS}

From the results of this study, it can be concluded that in Baybay City, Leyte, the high-strength-tunnel covered with polyethylene plastic has a lower initial investment cost than the net covered structure, but a higher investment cost than open field production. Highest gross margins are obtained from the protected cultivation as compared with the open field. The polyethylene plastic covered structure obtains the highest NPVs, BCRs, IRRs, and the earliest payback period across different scenarios, it is the more viable option. It is also not sensitive towards changes in yield and price.

In Cabintan, Ormoc City, the low-tunnel-structure is relatively cheaper than the high-strength-tunnel. Tomato grown within protective structures obtains higher margins than open field cultivation. The low-tunnel-structure proves to be the most profitable and viable investment if the produce is entirely sold in the Cebu market as compared with open field cultivations. Moreover, the high-strength-tunnel is most profitable if two croppings of tomato and a cropping of lettuce is produced each year.

Comparing the two structures, the low-tunnel-structure obtains the highest expected value, along with open field cultivation if all the produce is sold in the high value Cebu market. It will not be viable to invest in a protective structure if the produce is only sold in the relatively low priced local market. Thus, market is one of the critical factors affecting profitability and pricing.

It can also be concluded that open field cultivations are more sensitive to yield reductions during Tropical Cyclones. Yield reductions and structure damage during strong tropical cyclones (signal no. 3-5) also negatively affected NPVs for protective structures in Cabintan, particularly for low-tunnel structures. However, if higher prices and yields of tomato are achieved with the protected cropping this can increase profitability.

From the results of this study, the following policy recommendations and implications are drawn. First, the government and private sector should give financial and technical assistance to farmers. Protected cultivation shows a potential to increase yields of crops by a factor of four higher than open field cultivation. Investing in this technology can benefit farmers with increased revenue, 
increased profit and can improve their welfare. However, small-scale farmers cannot afford the initial investment cost. With this, the government through the Department of Agriculture (DA) is recommended to extend financial assistance for the establishment of the protective structures. The private sector should also extend technical assistance to farmers on how to effectively manage crops under protected cropping technology. Second, the government, academe, researchers and extension workers should help in linking farmers to high-end markets. Since investing in protected cultivation requires a high-end market to effectively generate higher profit, the government, academe, researchers, and extension workers is recommended to help farmers through a program or project by linking them to highend markets to effectively capture higher price for their produce, generate increased revenue; thus, increasing profit and early recovery of initial investment cost. Third, the local government units could help facilitate easier access to high value markets by improving farm-to-market roads. Farm-to-market roads improvement may reduce postharvest damage and reduce marketing cost. Fourth, farmers and investors should avail crop and structure insurance. Results of this study have found out that the risk of crop failure and structure damage is high especially with tropical cyclone signals no. 2, 3, 4 and 5 . With the occurrence of this phenomenon as highly uncertain, it is recommended that the farmers should avail farm insurance. Fifth, information on time to harvest for different crops and planting windows should be provided to help farmers' maximize profitability of off-season protected cropping production by timing their production in such a way that the harvesting period of a vegetable co-insides with the period with which the supply is low; thus, higher prices can be captured. And lastly farmers should be encouraged to rotate their crops to avoid successive crops from the same family to reduce the risk of increasing pest and disease severity with successive plantings.

\section{ACKNOWLEDGMENT}

We would like to thank the Australian Centre for International Agricultural Research (ACIAR) Integrated Crop Management (ICM) and Value Chain Component for allowing us to conduct this study. We are in deepest gratitude to the farmers, farmer cooperators, and experts for sharing their time and expertise in gathering the necessary information and in making this study possible.

\section{REFERENCES}

Armenia PT, Menz KM, Rogers GS, Gonzaga Z, Gerona R \& Tausa ER. 2013. Economics of vegetable production under Protected Cropping Structures in Eastern Visayas, Philippines. Smallholder HOPES - horticulture, people and soil. ACIAR Proceedings 139 (pp112-122). Australia: Australian Centre for International Agricultural Research

Asian Disaster Risk Center (ADRC). 2008. Asian Disaster Risk Reduction. Retrieved June 26, 2016, from http://www.adrc.asia/nationinformation.php? NationCode $=608$

Engindeniz S and Tuzel Y. 2006. Economic Analysis of Organic Greenhouse Lettuce Production in Turkey. Scientia Agricola 63(3):285-290 
Investment appraisal and risk assessment of protected vegetable

Gonzaga Z, Capuno O, Loreto M, Gerona R, Borines L, Tulin A, Mangmang JS, Lusanta DC, Dimabuyu \& Rogers GS. 2013. Low-cost protected cultivation: enhancing year-round production of high-value vegetables in the Philippines. Smallholder HOPES - horticulture, people and soil. ACIAR Proceedings 139 (pp123-137). Australia: Australian Centre for International Agricultural Research

Harrison S and Herbohn J. 2008. Financial and economic research methods. In Errington M (ed) ACIAR Training Manual 1. The University of Queensland, Australia: Australian Centre for International Agricultural Research

Polat AA, Durgac C \& Caliskan O. 2005. Effect of protected cultivation on the precocity, yield and fruit quality in loquat. Scientia Horticulturae 104:189-198

Seriño MN, Castillo G \& Ruales J. 2017. Survey on farm practices of small-scale vegetable farmers in the Southern Philippines. Annals of Tropical Research 39 (Supplement B):1-21

Sreedhara D, Kerutagi MG, Basavaraja H, Kunnal L \& Dodamani M. 2013. Economics of capsicum production under protected conditions in Northern Karnataka. Karnataka Journal of Agricultural Sciences 26(2):217-219

Tarannum, Naik HB \& Ahamed ZB. 2014. Economic Feasibility and Profitability of Carnation (Dianthus caryophyllus L.) Cultivation under Protected Condition. International Journal of Science and Nature 5(2):283-286

Yadav R, Kalia P, Choudhary H \& BrihamaDev ZH. 2014. Low-Cost Polyhouse Technologies For Higher Income and Nutritional Security. International Journal of Agriculture and Food Science Technology 5(3):191-196 